\title{
Ethical Codes and Cultural Context: Ensuring Legal Ethics in the Global Law Firm
}

Laurence Etherington

Nottingham Law School

Robert Lee

Cardiff Law School

Follow this and additional works at: https://www.repository.law.indiana.edu/ijgls

Part of the International Law Commons, Legal Ethics and Professional Responsibility Commons, and the Legal Profession Commons

\section{Recommended Citation}

Etherington, Laurence and Lee, Robert (2007) "Ethical Codes and Cultural Context: Ensuring Legal Ethics in the Global Law Firm," Indiana Journal of Global Legal Studies: Vol. 14 : Iss. 1 , Article 6.

Available at: https://www.repository.law.indiana.edu/ijgls/vol14/iss1/6

This Symposium is brought to you for free and open access by the Law School Journals at Digital Repository @ Maurer Law. It has been accepted for inclusion in Indiana Journal of Global Legal Studies by an authorized editor of Digital Repository @ Maurer Law. For more information, please contact rvaughan@indiana.edu.

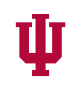

JEROME HALL LAW LIBRARY

INDIANA UNIVERSITY

Maurer School of Law
Blooming ton 


\title{
Ethical Codes and Cultural Context: Ensuring Legal Ethics in the Global Law Firm
}

\author{
LAURENCE ETHERINGTON* \& ROBERT LEE**
}

\begin{abstract}
There are doubtless many practical and professional problems that arise in the global legal practice, but this paper suggests that not least of these are issues of legal ethics, in part generated by the global context and not easily amenable to resolution by reference to any single code within the "home" or "host" jurisdiction. For example, there may be difficulties in isolating precisely what those ethical obligations might comprise. These obligations might be rooted in the requirements of local law, but they might arise equally from the values and expectations of the client, or from other lawyers whether inside or outside of the firm in question. The common expectation of regulatory control exercised by a professional bar may be replaced by a fluidity in which clearly defined rules and duties are not easily discernible. The questions that this paper seeks to answer are: How might lawyers best be provided with and follow ethical approaches appropriate to the delivery of global legal services, and what is the role that firms might play in achieving this?
\end{abstract}

\section{INTRODUCTION}

The European Union in its drive towards a single market in goods and services emphasizes free movement not only of those goods and services but also of labor and capital. A strong agenda of liberalization stresses de-regulation, privatization, and

*Reader in Environmental Law, Nottingham Law School; laurence.etherington@ntu.ac.uk

**Professor of Law, Cardiff Law School, Co-Director ESRC Research Centre for Business Relationships, Accountability, Sustainability and Society, Cardiff University; Leerg@cardiff.ac. uk. A form of this paper was delivered at the $14^{\text {th }}$ Annual IJGLS Symposium, Globalization of the Legal Profession, by Bob Lee and the authors are grateful for the comments of participants, which helped shape the paper.

Indiana Journal of Global Legal Studies Vol. 14 \#1 (Spring 2007)

OIndiana University School of Law 
economic integration. Not only have law firms serviced and supported this agenda, but also their growing international presence is itself evidence of the consolidation of the services market in Europe. Law firms are actors in the play that they help to produce. What is striking about the development of pan-European law firms is that they draw together lawyers from very different legal and cultural traditions. As multi-national corporations push the globalization of legal practices, in seeking consistent, onthe-spot representation and integrated cross-border services, European law practices have faced some of the same issues as their clients in coping, through the process of globalization, with heterogeneity in areas such as language, culture, and currency.'

Arguably, such problems have been less prevalent for North American firms extending their global reach. ${ }^{2}$ This is because of the favored strategy option of expanding through the opening of foreign offices rather than through merger or alliances with, or the franchising of, local law firms. In building up a national presence, and then in taking the practice overseas, the U.S. law firm has managed its expansion in a more homogenous context. Indeed this form of expansion by U.S./Anglo law firms has given rise to charges of "cultural imperialism" whereby alternative foundations of law and society are threatened or even overridden. ${ }^{3}$ There is some truth in this, as part of the enterprise of global lawyering has been to facilitate the climate for international investment by opening up markets and rolling back state regulation ${ }^{4}$ in a manner which may displace earlier, shared collective values in many jurisdictions.

In the world of globalized legal services, we might not be too surprised to find an Australian lawyer working in the Brussels office of a New York law firm on a contract for a Japanese client with a German counterpart, which is governed by

1. See Steven Mark, Harmonization or Homogenization? The Globalization of Law and Legal Ethics-An Australian Viewpoint, 34 Vand. J. Transnat'L L. 1173, 1182-83 (2001); John P. Heinz, Robert L. Nelson \& Edward O. Laumann, The Scale of Justice: Observations on the Transformation of Urban Law Practice, 27 Ann. Rev. Soc. 337, 359 (2001).

2. Indeed there is a level at which it can be argued that U.S. law firms under the forces of globalization have become more and not less homogenous. See generally Carole Silver, Globalization and the U.S. Market in Legal Services-Shifring Identities, 31 Law \& Pol'y Int'l Bus. 1093 (2000) (discussing how internationalization has resulted in the homogenization of the largest U.S. law firms because they must compete for a limited group of clients and lawyers).

3. For a consideration of the concept of cultural imperialism, see Susan Marks, Empire's Law, 10 Ind. J. Global LeGal Stud. 449, 451-52 (2003) and Mark, supra note 1, at 1179-80.

4. See generally Edward S. Cohen, Allocating Power and Wealth in the Global Economy: The Role of Private Law and Legal Agents (Univ. of Warwick Ctr. for the Study of Globalisation \& Regionalisation, Working Paper No. 101/02, 2002), available at http://www2.warwick.ac.uk/fac/soc/csgr/ research/workingpapers/2002/wp10102.pdf (arguing that lawyers working for global corporate law firms help to define and diffuse legal rules of the global economy, thus in part determining the distribution of power and wealth that results). 
English common law, but in which disputes are to be referred to the International Chamber of Commerce's International Court of Arbitration based in Paris. There are doubtless many practical and professional problems that arise in such situations of global legal practice, but, in this paper, we wish to suggest that not least of these are issues of legal ethics, in part generated by the global context and not easily amenable to resolution by reference to any single code within the "home" or "host" jurisdiction. For example, there may be difficulties in isolating precisely what those ethical obligations might comprise. These obligations might be rooted in the requirements of local law, but they might arise equally from the values and expectations of the client, or from other lawyers whether inside or outside of the firm in question. The common expectation of regulatory control exercised by a professional bar may be replaced by a fluidity in which clearly defined rules and duties are not easily discernible. The questions that this paper seeks to answer are: How might lawyers best be provided with and follow ethical approaches appropriate to the delivery of global legal services, and what is the role that firms might play in achieving this?

Before addressing these questions it is useful to elaborate a little further on the impact of globalization upon legal ethics. An obvious issue is that a law firm operating in a number of jurisdictions may face problems in accommodating potentially conflicting ethical codes. The problem is not only spatial, but is to some degree temporal. ${ }^{6}$ This is because the traditional understandings and values laid down over time and embedded into the very strata of the codes are slowly eroded by the tide of globalization. Globalization is not a neutral force. In pursuit of economic integration, it drives to open up markets and further market choice. Much of what lies within professional conduct rules is antithetical to its purpose, as these rules have been supportive generally of state-sanctioned restrictive practice regulating the delivery of legal services in return for assurances of ethical behavior.? Justifications for

5. See generally Laurel S. Terry, U.S. Legal Ethics: The Coming of Age of Global and Comparative Perspectives, 4 Wash. U. Global Stud. L. Rev. 463, 470-72, 523-26 (2005) (arguing that theorizing about legal ethics in transnational lawyering has often lagged behind the reality of legal practice).

6. Disjunctions between space and time are a hallmark of globalization. See generally ANTHONY Giddens, Modernity and Self-Identity 14-21 (1991) (arguing that in the "pre-modern" world, time and space were connected through place, but in the modern world there is a separation of time and space because the global map has no privileging of place); James H. Mittelman, The Dynamics of Globalization, in Globalization: Critical Reflections 1, 3 (James H. Mittelman ed., 1996) (arguing that globalization compresses the time and space aspects of social relations).

7. Such practices might be under direct threat from the General Agreement on Trade in Services (GATS) of the WTO. See generally Paul D. Paton, Legal Services and the GATS: Norms as Barriers to Trade, 9 New ENG. J. INT'L \& CoMr. L. 361 (2003), available at http://www.nesl.edu/intljournal/vol9/paton.pdf (discussing the conflict between global and domestic forces in shaping 
market intervention and the allowance of a monopoly right to provide legal representation based on arguments of informational asymmetry ${ }^{8}$ are less and less persuasive to those supporting the market liberalization agenda inherent in the globalization of services delivery. Threats to legal ethical frameworks under globalization are, therefore, not only confined to a clash of cultures but also include a clash of values. ${ }^{9}$

\section{Globalization and Legal Practice}

The types of economic liberalization witnessed in the European Union have presented considerable opportunities to law firms in general and to the larger firms of U.S. and British origin in particular. These firms began with a built-in advantage of size generally not shared by continental European firms. Size and profitability allowed these firms the base to expand into new global markets for legal services, but so too did other built-in advantages..$^{10}$ First, there is the advantage of language, with English becoming the language of globalization. ${ }^{11}$ Second, there has been the advantage (for U.S. firms) of the dominance of the U.S. dollar as the global currency ${ }^{12}$ to the point at which U.S. dollar denominated deposits, held initially at European banks in an early attempt to create a regulatory vacuum, gave rise to their own financial market in Eurodollars. Third, and most important for legal practice, the experience of the process of liberalization in home jurisdictions under Reagan and Thatcher and the growing dominance of

ethical rules for the legal community); Joseph McCahery \& Sol Picciotto, Creative Lawyering and the Dynamics of Business Regulation, in Professional Competirion and Professional Power: Lawyers, Accountants and the Social Construction of the Market 238 (Yves Dezalay \& David Sugarman eds., 1995) (discussing business regulation and the effect it has on lawyering).

8. E.g., R. C. O. Matthews, The Economics of Professional Ethics: Should the Professions Be More Like Business?, 101 Econ. J. 737, 739-41 (1991); Anthony Ogus, Rethinking Self-Regulation, 15 O. J.L.S. 97, 97-98 (1995) (U.K.). For a discussion of the changing regulatory schemes governing the legal profession, see Alan A. Paterson, Professionalism and the Legal Services Market, 3 INT'L J. Legal Prof. 137, 145-49 (1996).

9. This is not to underplay the importance of culture clashes, which are considered in detail below, but perhaps the clash of values is indicated by the erosion of professional structures, taking place within jurisdictions as well as across them. For a U.K. perspective, see Andrew M. Francis, Legal Ethics, the Marketplace and the Fragmentation of Legal Professionalism, 12 INT'L J. Legal Prof. 173 (2005). For a U.S. perspective, see Herbert M. Kritzer, The Professions Are Dead, Long Live the Professions: Legal Practice in a Postprofessional World, 33 L. \& Soc'y Rev. 713 (1999).

10. See John Flood, Megalawyering in the Global Order: The Cultural, Social and Economic Transformation of Global Legal Practice, 3 Int'L J. Legal Prof. (Special Issue) 169, 177 (1996); Marc Galanter, Law Abounding: Legalisation Around the North Atlantic, 55 Mod. L. REv. 1, 5 (1992).

11. Mark, supra note 1, at 1178-79.

12. Id. 
common law to govern global transactions, led out of the financial centers of London and New York, delivered obvious advantages. To the extent that globalization has been characterized by increased "legalization," in the primacy being given to freedom of contract and protection of individual property rights, the underlying philosophy of the common law ${ }^{13}$ served this program well.

Armed with such advantages, Anglo-American law firms took an early lead in selling legal services to facilitate the globalization enterprise. Elsewhere in this issue, there are detailed depictions of the nature and scope of the dominance of such firms in the global marketplace. We have no wish as such to repeat this analysis, though we do rely upon it and it may assist to point to just some features of legal activity in the global market place. The first is that the value of this market grows year by year, driven especially by the development of international capital markets. Second, there seems to be a distinction between those firms servicing cross-border activity in this global market and those that help build the market itself. In other words, as goods and services cross borders, there is ample work for "transnational firms" in either arranging the business forms and structures ${ }^{14}$ that facilitate this work or in servicing the work directly. ${ }^{15}$ However, we might make the claim that the true global players, the "global firms," are those directly concerned with global finance through the arrangement and structuring not of the activity within the markets, but of the markets themselves. This would be true for capital markets work, project finance, and other large-scale syndicated bank funding of, for example, the structures of the new privatized economies..$^{15}$

There may be differences between these types of services, which might be reflected correspondingly in the law firms that provide each type. Firms positioned for cross-border trade work may depend on a capacity to deliver local legal services, such that rights can be protected locally, judgments enforced, or regulatory hurdles overcome. The firms with global finance practices, in contrast, may be much less

13. Id.; see also R. Daniel Kelemen \& Eric C. Sibbitt, The Globalization of American Law, 58 INT'L Orc. 103, 106, 111 (2004) (arguing that economic liberalization and political fragmentation have undermined traditional approaches to regulation and provided incentives to shift toward U.S. legal style).

14. Business forms and structures can be arranged by mergers and acquisitions, joint ventures or other forms of transactional activity, or in ensuring that the structures comply with competition and other forms of regulation.

15. Firms can service the work directly by overseeing the contracts, together with associated finance, shipping or insurance contracts, ensuring the protection of intellectual and other property rights and enforcing those rights or resolving commercial disputes across jurisdictional boundaries.

16. Because of this distinction between transnational and global firms, we have tried to adopt a generic label of 'international firms' when referring to both types of firms. 
concerned about local law capacity so that rather than offices in a wide range of jurisdictions, there is more likely to be a concentration on one or more of the key financial centers of New York, London, and Tokyo. ${ }^{17}$ This profile suggests that, while there are many cross-border firms, the truly global firms are members of a rather exclusive club, access to which is so costly that it cannot be bought, depending as it does on human capital in the form of networks of clients from the merchant banking community. In so far as we posit the difficulties of operating a framework of legal ethics across offices that operate in different cultures and jurisdictions, it may be that this is less of a problem for the truly global firm than for the international firm providing cross-border services based on local law.

For both types of firms, however, globalization will present a context within which issues of ethics arise. These may be somewhat wider than the traditional realm of legal ethics. For example, will the project being financed in a developing country create questions of corporate social responsibility if indigenous people are to be displaced or biodiversity threatened? Even if the lawyers feel unconcerned about providing services to support such activity, they may feel it prudent to point out the legal and other risks that may attach to that activity. Interestingly, this is an area in which international banks have chosen to regulate their own activity by adopting what have become known as the Equator Principles. ${ }^{18}$ These voluntary principles are based on the International Finance Corporation (IFC) Environmental and Social Standards and apply globally to development projects in all industry sectors with capital costs of $\$ 10$ million or more..$^{19}$ Given that the banks will look to their

17. This is reflected to a large degree by Carole Silver's analysis of the presence of U.S. law firms in cities around the world. See Silver, supra note 2, at 1108, 1122-24 (examining the patterns of location and number of foreign offices for U.S. law firms). In addition to the cities cited above, Frankfurt (another financial center), Brussels (home of the European Economic Community (EEC)), Paris (home of the International Chamber of Commerce (ICC) and Organisation for Economic Cooperation and Development (OECD)) and Hong Kong (providing more congenial economics than other Asian locations) are other foreign locations with obvious attractions for the cross border law firms. Id. at 1108-11, 1118, 1120-22. For a British perspective on U.S. expansion into Europe and Pacific Asia, see J.V. Beaverstock, R.G. Smith \& P.J. Taylor, Geographies of Globalization: United States Law Firms in World Cities, 21 Urb. Geography 95 (2000).

18. Over forty institutions have adopted the principles at the time of writing. International Finance Corporation, Our Approach to Sustainability (2006), http://www.ifc.org/equatorprinciples. For the full text of the revised Equator Principles, see The "Equator Principles": A Financial Industry Benchmark for Determining, Assessing and Managing Social \& Environmental Risk in Project Financing, July 6, 2006, available at http://www.equator-principles.com/documents/Equator_Principles.pdf.

19. Malcolm Forster, The Equator Principles--Towards Sustainable Banking?, 2005 Butterworths J. Int'L Banking \& Fin. L. [JIBFL] 217; Paul Watchman, Banks, Business and Human Rights, 2006 JIBFL 46,50 n.2. 
lawyers to incorporate the relevant standards within the conditions and covenants of the lending document, it will be necessary for the law firms to develop an understanding of the business ethical requirements of their clients.

Concerns have been expressed for decades about the perceived shift in the legal practice from profession to business. ${ }^{20} \mathrm{~W}$ ithout entering this debate, ${ }^{21}$ it might be said that the scale of operations within law firms equipped to provide global legal services of any type necessitates that these firms are managed along proper business lines. This is to ensure what Ronald Pol and Patrick McKenna have described as the "quest for seamless service."22 In other words, it is widely perceived by law firms that clients will demand the same service standards from whichever international office they choose to access. There is no simple dividing line between ethical standards and other quality standards. Often the ethical rule, as with, say, conflicts' rules, will have the effect of offering the client some assurance, thereby ensuring client satisfaction. It follows that the assurance of ethical standards may form a part of the expectation of the client, alongside more commercial issues such as how bills are calculated and prepared. Clients will expect consistency through the coordination of standards. It may be part of the criteria that the client will use to assess the quality of management in the law firm.

It may be tempting to describe the ethical rule as emerging because of the need to ensure client satisfaction, but Rick Abel has identified professional conduct rules as attaching to lawyers as an occupational group that seeks, out of self interest, to assert "a substantial degree of control over the market for their services." ${ }^{23}$ This is safer than the prospect of being controlled by the market, which is said to be fraught with "uncertainty" to the point that it might lead to "extinction." ${ }^{24}$ This thesis is in opposition with notions that the primary purpose of the

20. Marc Galanter \& Thomas Palay, Large Law Firms and Professional Responsibility, in LEGAL Ethics and Professional Responsibility 189, 190-93 (Ross Cranston ed., 1995).

21. This debate has recently been subject to criticism. See Daniel Muzio \& Stephen Ackroyd, On the Consequences of Defensive Professionalism: Recent Changes in the Legal Labour Process, 32 J.L. \& Soc'y 615, 619 (2005).

22. See generally Ronald F. Pol \& Patrick J. McKenna, The Quest for Seamless Service: Ensuring Consistency with Multioffice Law Firms, ACC Dock Eт, Jan. 2005, at 34 (discussing the need for law firms to ensure that their branch offices meet the same high standards as their main office to satisfy their corporate clients).

23. Richard L. Abel, England and Wales: A Comparison of the Professional Projects of Barristers and Solicitors, in I Lawyers in Society: The Common Law World 23, 23 (Richard L. Abel \& Philip S. C. Lewis eds., 1988).

24. Id.; see also Richard L. Abel, American Lawyers 20 (1989); Richard L. Abel, The Legal Profession in England and Wales 10-11 (1988); R. G. Lee, From Profession to Business: The Rise and Rise of the City Law Firm, 19 J.L. \& Soc'y (SPECIal Issue) 31, 31 (1992). 
professional group is to uphold some wider ethical standard as a bulwark to clients' potential demands that could run against wider public interests such as the administration of justice. ${ }^{25}$ Abel's thesis is that, in response to competition in a free market, which might otherwise undermine many of the traditional social advantages enjoyed by lawyers, it was prudent for the legal profession to regulate and control its own market through the imposition of professional standards.

In his later work, Abel sees signs of loosening these controls over the market for legal services at the hands of increasingly powerful clients and in the face of significant economic and organizational changes, which have made market control increasingly problematic. ${ }^{26}$ This decline is also aided by larger numbers of entrants to the market joining increasingly large firms that operate in bigger and bigger business units. Professional cohesion can be undermined, suggests Abel, by too great or permanent a stratification within the structure of the profession itself. Abel suggests that "the principal division among solicitors is firm size." Increasingly, there is a gulf between the larger and the smaller firms that translates into differences in client base, work type, and firms' and partners' earnings. It may also affect the way in which the firms perceive, organize, and manage themselves. The difference is between traditional partnership models ruled by consensus amongst the partners and more modern managerial structures in the larger firms where much of the day-to-day responsibility for business decisions has been conceded by the partnership. If this is so, the move in the international large law firm to a focus on shared ethical understandings to ensure an evenness of client service standards may be accompanied equally by a decline in the persuasiveness of self-imposed professional conduct rules. ${ }^{27}$

To elaborate further on the service quality element, we suggest that the maintenance of quality may demand some shared understandings of the ethical frame-

25. See, e.g., Talcott Parsons, Professions, in 12 International Encyclopedia of the Social Sciences 536, 536-37 (1968); Mark J. Osiel, Lawyers as Monopolists, Aristocrats, and Entrepreneurs, 103 Harv. L. Rev. 2009, 2009-11 (1990) (reviewing 1 Lawyers in Society: The Common Law World (Richard L. Abel \& Philip S.C. Lewis eds., 1988); 2 Lawyers in Society: The Civil Law World (Richard L. Abel \& Philip S.C. Lewis eds., 1988); 3 Lawyers in Society: Comparative Theories (Richard L. Abel \& Philip S.C. Lewis eds., 1989)).

26. Richard L. Abel, Ten Years On: Changes in the Regulatory Framework, in Gover ning ThE Profession: Proceedings From The Law Society Annual Research Conference (The Law Society ed., 1998); see also Richard L. Abel, English Lawyers Between Market and State: The Politics of Professionalism 202-39 (2003).

27. See Geoffrey C. Hazard, Jr., The Future of Legal Ethics, 100 YALE L.J. 1239, 1241 (1991). Note that when we refer to Professional Codes in this paper, we refer to those that emanate out of selfregulation so that they are promulgated by the Bar or Law Society. One of the curiosities is that market liberalization seems to offer no freedom from external regulation of some kind. It is selfregulation, rather than regulation per se that is under attack. 
work in which lawyers must operate. This is not only because clients may have expectations of how they will be treated, so that, for example, confidences are not breached, but also because ethical rules themselves may be shaped according to local legal standards. For example, disclosure of a client's affairs, in litigation or to a regulator, may be governed by local law in a manner that does not accord with treatment in the client's home jurisdiction. Or a substantive legal requirement may influence the entire conduct of legal affairs. A good example would be the requirement of good faith in contractual negotiations under many civil law systems. This is in distinct contrast to a caveat emptor standard of bargaining at common law, which places the requirement of scrutinizing risk on the buyer, so that failure to disclose on the part of the seller is positively encouraged. ${ }^{28}$ It follows that developing legal skills-such as those of negotiation-by lawyers across the international firm may require a reprogramming of earlier legal training in which background assumptions of the way to behave as a lawyer are put aside. Worse, the lawyer might be expected to operate according to different standards depending on whether the contract is governed by common or civil law.

\section{Conflicts in Ethical Duties}

The difficulties arising out of this complex layering of professional duties-or "double deontology"29 — should not be overstated. In general, "there are fundamental principles of legal professional ethics which can be found, in one form or other, in most jurisdictions." 30 There are, however, even significant differences between common law jurisdictions. For example, the "conflict of interests" duty is very different for U.S. lawyers, who enjoy much greater freedom to act where there is client consent than do English lawyers, for whom the situation is also muddied by different requirements under professional regulations and at common law. This reflects a

28. This is an interesting mechanism favored on grounds of incentive compatibility, which requires the buyer to determine an appropriate level of investment in diligence. See Matthews, supra note 8 , at 739 .

29. Donald Nicolson \& Julian Webe, Professional Legal Ethics: Critical Interrogations 62 (1999). The basic position is that lawyers practicing as foreign legal advisors are required to comply with the local ethical code as well as their home professional standards (to some degree at least). Council Directive 77/249/EEC, To Facilitate the Effective Exercise by Lawyers of Freedom to Provide Services, arts. 4, 6, 1977 O.J. (L 78) 17, 18 (EC); see Julian Lonbay, Legal Ethics and Professional Responsibility in a Global Context, 4 Wash. U. Global Stud. L. Rev. 609, 611-12 (2005).

30. Alison Crawley \& Christopher Bramall, Professional Rules, Codes, and Principles Affecting Solicitors (Or What Has Professional Regulation to do With Ethics?), in Legal Ethics And ProfesSIONAL ResPonsibILITY, supra note 20, at 99,99. 
clearer focus on the duty to the client for U.S. lawyers, whereas lawyers in some other countries have more diverse duties beyond those owed to the client. ${ }^{31}$ Similar differences exist in areas such as attorney-client privilege and contingency fees. ${ }^{32}$ Differences in practice rules may reflect the local context. For example, advocates involved in conveyancing on the Isle of Man were traditionally allowed to act for both sides in property sale or purchase transactions, a rule which probably reflected the small size of the profession on the Island, but which has been revised recently, reflecting the growth in the profession and burgeoning development on the Island. ${ }^{33}$

Perhaps more importantly, variations in approaches to ethical duties are beginning to become apparent among lawyers in England and Wales, reflecting tensions in an increasingly stratified and divergent legal profession. The English legal profession has been increasingly polarized, with a split between those lawyers servicing private individuals through small practices across the country and those servicing commercial clients as part of increasingly large organizations. ${ }^{34}$ The relative equality of knowledge between client and advisor in the latter case dictates that the consumer protection rationale for the imposition of professional standards is less relevant, at least in some cases. Of course, there are still rationales for the requirement of professional ethics which relate to wider public values, such as the need for independence in all branches of the administration of justice, but the breaking down of regulatory barriers to open up competition is increasingly asserted as being in the public interest by promoting consumer choice. ${ }^{35}$ Traditionally, it is the wider duties to the public interest and the preparedness to refuse to act that might distinguish lawyers from other professions, since strict adherence to an ethical code is likely to

31. Nancy J. Moore, Regulating Law Firm Conflicts in the 21st Century: Implications of the Globalization of Legal Services and the Growth of the "Mega Firm", 18 Geo. J. Legal Ethics 521, 528 (2005) (review essay).

32. Mark, supra note 1, at 1185 (discussing Australia in particular). The German Bar has outlawed contingency fees even though they would apparently not be ruled unenforceable as sufficiently immoral (contra bonos mores) by the courts. Detlev F. Vagts, Professional Responsibility in Transborder Practice: Conflict and Resolution, 13 Geo. J. Legal Ethics 677, 683 (2000).

33. Compare Stephen Crow, Isle of Man: Report of an Inquiry into Planning and Other Matters at Mount Murray 13, II 2.29-2.30 (2000), available at http://www.gov.im/infocentre/ archived_releases/pdfs/Entire_crow_report.pdf (status of regulations in 2000), with J.P. SHIMmin, A.C. Douglas \& E.G. Lowey, Report of the Select Committee on the Compensation Claim-Mount Murray Residents 8, II II 3.12-3.14 (2005), available at http://www.tynwald.org. $\mathrm{im} /$ papers/reports/2004/main.shtml (status of regulations in 2004).

34. Gerard Hanlon, A Profession in Transition?-Lawyers, the Market, and Significant Others, 60 Mod. L. Rev. 798, 799 (1997).

35. Harry McVea, Predators and the Public Interest-the 'Big Four' and Multi-Disciplinary Practices, 65 Mod. L. Rev. 811, 820-21 (2002). 
lead to the loss of work. ${ }^{36}$ More cynically, lawyers are unlikely to want ethical standards to erode to the point where the maintenance of a "professional monopoly" becomes untenable. ${ }^{37}$ Instead, the desire is to have standards and approaches which match the reality of the commercial context of the practice of law. It appears that the tensions that result from a common regulatory and professional body have resulted in at least some commercial firms operating to their own standards, informed and policed by their clients. ${ }^{38}$ This deregulatory approach is likely to find some institutional support in reform of the legal profession in England and Wales. ${ }^{39}$

\section{Cultural Basis of Ethics}

Professional conduct rules reflect shared values or beliefs about how lawyers ought to behave. It will be clear from the text above that this may be with a view to arriving at a particular end or goal. Thus, the rule may be to respect client confidentiality in order, at least in part, to engender client trust. The value of client trust generates the rule or precept that we should respect and keep confidences. According to Wines and Napier, "[e]thics is the systematic application of moral principles to concrete problems." ${ }^{40}$ For instance, when faced with a request for information about the activity of a client for whom the lawyer has worked, the lawyer will need to apply the rule ("respect client confidentiality") in this specific

36. Strict adherence to an ethical code might also lead to some loss of face for the lawyer concerned. See Emmanuel lazega, The Collegial Phenomenon: The Social Mechanisms of Cooperation Among Peers in a Corporate Law Partnership 274-75 (2001).

37. See Abel, English Lawyers, supra note 26, at 486-91 (examining changes in the legal profession in England and Wales, including the dwindling ability of the profession to keep control of its monopolies).

38. Robert Lee, Firm Views: Work of and Work in the Larcest Law Firms 24-29 (1999); see also Janine Griffiths-Baker, Serving Two Masters: Conflicts of Interest in the Modern Law FIRM 122-41 (2002) (arguing that while the large corporate firms quietly ignore conflicts rules, the smaller firms adhere to them fully). But see Susan P. Shapiro, Tangled Loyalties: Conflict of Interest in Legal Practice 437 (2002) (showing that conversely, in the United States, the largest law firms expend considerable effort and expense to continue representing their clients in the face of a confict and that corporate clients often welcome and exploit such rules to their advantage).

39. The English government seems increasingly committed to the removal of restrictive practices and supports a more open form of competition between those willing to provide legal services. See, e.g., Joint Committee on the Draft Legal Services Bill, Draft Legal Services Bill, Volume 1: Report, 2005-6, H.C. 1154-I, H.L. 232-I; Department for Constitutional Affairs, Draft Legal Services Bill, Explanatory Notes and Regulatory Impact Assessment, 2006, Cm. 6839 [hereinafter Explanatory Notes and Assessment].

40. William A. Wines \& Nancy K. Napier, Toward an Understanding of Cross-Cultural Ethics: $A$ Tentative Model, 11 J. Bus. EтHics 831, 831 (1992). 
situation. This might not lead, however, to a blanket refusal to make disclosure because other rules, such as "further the administration of justice," might conflict with such action. An ethical standpoint, for example, disclosing only when required to do so by a court order, will be arrived at by the analysis of the application of the rules to the real life problem at hand. Thus, professional ethics involve decisions that will govern conduct in accordance with cultural norms. ${ }^{41}$

It is clear, however, from observation of confidentiality rules in areas such as banking or medicine, that some cultures of confidentiality are stronger than others. It is easy to recognize the broad, shared value of confidentiality, but it may be held with different degrees of commitment in different cultures. Switzerland has historically pursued a very strong line of banking secrecy, and while this may have served its economic interest in attracting deposits to Swiss banks, there is no reason to argue that this stance is morally weaker than that of surrounding countries which more readily disclose banking information. Moreover, a banker preserving absolute client confidentiality in the face of doubts as to the provenance of the money might be viewed in such a culture as a model professional even though such conduct might be castigated as underhanded or ethically dubious according to the professional standards in another cultural setting.

The identification of differing ethical rules and the foundations from which these differences arise demonstrate that professional ethics are culturally distinct. In relation to legal ethics, these cultural differences may reflect aspects of different legal cultures, but they may also reflect differences in wider social structures and values. Indeed, it is possible that the very commitment to, and understanding of, ethical principles is different in different jurisdictions, reflecting differing intellectual traditions or patterns of education. Equally, even when there is a shared commitment to a value, its manifestation in certain forms of conduct may be problematic. By way of illustration, take a series of television advertisements for HSBC Bank shown in the United Kingdom under the strap-line "The World's Local Bank." The purpose of the campaign has been described as follows: "HSBC commercials typically show the effects that different meanings for the same word or gesture have in different countries, which is intended to convey that HSBC's operations in 77 countries prepare the bank for helping customers wherever they are. ${ }^{142}$

41. See generally Larry R. Churchill, The Teaching of Ethics and Moral Values in Teaching: Some Contemporary Confusions, 53 J. Higher Educ. 296 (1982) (discussing the misconception concerning the relation between teaching ethics and the way individuals make moral decisions in reality).

42. Stuart Elliot, A Bank That Isn't Your Average New Yorker Is Starting to Spread the NewsAbout Itself, N.Y. Times, Apr. 19, 2005, at C5. 
One title in the series shows an English businessman being entertained by a group of Chinese businessmen in a Chinese restaurant. ${ }^{43}$ The English man struggles to eat the eel served to him but finishes every last bit. This is to the consternation of his Chinese hosts, who then serve an even bigger eel to the alarm of the guest and so on. The voiceover states that: "the English believe that it's a slur on your hosts' food if you don't clean your plate; whereas the Chinese feel you are questioning their generosity if you do."44 Clearly, both parties share the value and recognize the importance of gratitude, but its expression takes very different forms within the cultures concerned.

As well as culturally derived professional rules and other norms, lawyers and legal professions also operate within differing social and cultural environments, such as social hierarchies. Their ethical behavior is influenced by many contexts, including the type of work they do, their positions within hierarchies, and the nature of their clients. ${ }^{45}$ The hierarchies themselves may not be based on the Anglo-American tournament to partnership, ${ }^{46}$ especially where firms are historically of a small size, or may be influenced by other prevailing hierarchies in society-as reflected, for example, in Indian society. Values, beliefs, and behavioral norms influence not only group members' behavior, but also their interpretations of the "meaning" of other peoples' behavior. ${ }^{47}$ Lawyers working within an increasingly rich cultural environment need to have or to develop intercultural awareness skills, so that they are able to communicate effectively with others who do not share common cultural experiences. ${ }^{48}$ One aspect of these necessary skills is an awareness of, and sensitivity to, differences in professional ethics.

43. Crave Online, Spiked Humor, HSBC Commercial-English Man in Chinese Restaurant, http://www.spikedhumor.com/articles/27377/English_Man_In_Chinese_Restaurant.html (last visited Oct. 21, 2006).

44. Id.

45. Nicolson \& WeBb, supra note 29, at 51.

46. See generally Marc Galanter \& Thomas Palay, Tournament of Lawyers: The TransforMation OF THE BIG LAW FirM (1991) (discussing how the structuring of compensation and incentives around a promotion-to-partner contest has transformed the big law firm in the United States).

47. Helen Spencer-Oatey, Introduction to Culturally Speaking: Managing Rapport Through Talk Across Cultures 4 (Helen Spencer-Oatey ed., 2000).

48. See generally Geert Hofstede \& Gert Jan Hofstede, Cultures and Organizations: Software of the Mind: Intercultural Cooperation and Its Importance for Survival (2005) (discussing the importance of intercultural cooperation for the survival in the business world); Fons Trompenaars \& Charles Hampden-Turner, Riding the Waves of Culture: Understanding Cultural Diversity in Global Business (2d ed. 1998) (discussing cultural differences and the impact those differences have on the process of doing business and managing). 
The wider world of business has had to grapple with the impact of globalization upon ethical issues, including religious and cultural pluralism, within, as well as between, countries. One strategy is to seek to develop a system of global business ethics, though this is an extremely complex and demanding task. ${ }^{49}$ It may also be a problematic approach because of the problems of cultural imperialism, which are particularly stark where harmonized systems, reflecting the economically liberal values of globalization, may be perceived as homogenization based on Western standards. ${ }^{50}$ The development of an international code of ethics for lawyers began in the $1950 \mathrm{~s},{ }^{51}$ though, notwithstanding the significant expansion of global legal services in the last twenty years, these codes have remained rather static instruments. ${ }^{52}$ While harmonized systems might provide the desired efficiency in delivery of legal services, there are a number of problems that might attach to them. There is a great danger that they might erode moral pluralism and fail to adequately reflect local cultures, values, and identities. ${ }^{53}$ There is also the risk that such codes are based on compromises around what is easily acceptable from the various jurisdictions and avoid controversy by a minimalist approach to ethics. $^{54}$

49. E.g., Georges Enderle, Business Ethics, in The Black well Companion To Philosophy 531, 531-32, 546 (Nicholas Bunnin \& E.P. Tsui-James eds., 2d ed. 2003).

50. See Mark, supra note 1 at 1178. For a wider perspective on this issue, see Jacques AtTali, Millennium: Winners and Losers in the Coming World Order 117-30 (Leila Conners \& Nathan Gardels trans., Random House 1991) (1990).

51. Nicolson \& WEBB, supra note 29, at 62. For a copy of the latest version of this code, see IntERnAtional Bar Association, International Code of Ethics (1988), available at http:/www.ibanet.org/images/downloads/International_Ethics.pdf.SeeCouncilof the Bars and Law Societies of the European Union, Code of Conduct for Lawyers in tHe European Union (2002), available at http:/www.ccbe. org/doc/En/code2002_en.pdf, for the European code that enshrines many similar provisions.

52. See generally Andrew Boon \& John Flood, Globalization of Professional Ethics? The Significance of Lawyers' International Codes of Conduct, 2 LEGAL ETHICs 29, 55-56 (1999) (arguing that the absence of discourse about the international codes is a barrier to the globalization of professional ethics); $\mathrm{H}$.W. Arthurs, A Global Code of Ethics for the Transnational Legal Field, 2 Legal ErHics 59 (1999) (discussing the difficulties of creating a universal or global code of ethics and criticizing such codes as ineffective); Mary C. Daly, The Ethical Implications of the Globalization of the Legal Profession: A Challenge to the Teaching of Professional Responsibility in the Twenty-First Century, 21 Fordham INT'L L.J. 1239, 1248-49 (1998) (pointing to the lack of take-up of global ethics issues within the law curriculum).

53. Ana Marta González, Ethics in Global Business and in a Plural Society, $44 \mathrm{~J}$. Bus. Etrics 23, 23-24 (2003); Mark, supra note 1, at 1178.

54. González, supra note 53, at 24; see also Mark, supra note 1, at 1187; Spencer-Oatey, supra note 47 , at 5 . By 'minimalist' we mean that instead of an inclusive set of ethical values, consensus is reached by focusing on a core set of universal values. The advantage might then be to lay the foundations from which further negotiation can proceed. See Sissela Bok, What Basis for Morality? A Minimalist Approach, 76 Monist 349, 352-53 (1993). 


\section{The "Virtuous" Approach to Professional Ethics}

In line with the philosophy of globalization, there has been a shift from ethical regulation of commercial legal practice to market-based regulation, with the consequence that issues such as reputational risk in the market (considered below) are more important to firms than threats of professional, non-market discipline. In fact, there is evidence that powerful clients see their ability to hire and fire as a better form of insurance against unethical action by legal advisors than professional regulation. ${ }^{55}$ Of course this might go beyond ethical compliance to more general "compliance" with a client's wishes, and independence of commercial firms from their major business clients has been a concern for some time. ${ }^{56}$ The question arising here is whether independence is best secured through increasing regulatory control or through some other means.

Nicolson has expressed concerns over the ability of externally imposed professional codes to ensure that lawyers uphold high ethical standards. ${ }^{57}$ While not expressly directed at the issues faced by international firms, his suggestions as to a better approach seem particularly helpful for professionals operating within this more ethically complex environment. Problems of "deontic," or duty based, approaches to professional ethics are identified as: reducing standards to the lowest common denominator; ${ }^{58}$ requiring the reduction of moral issues to codes or formulae; failing to ensure sensitivity to issues arising; and neglecting the requirement for judgment to identify and analyze problems and potential solutions. Most importantly, these approaches also assume that individuals have both the motivation to want to act correctly and the courage to do so in the face of temptations and pressures to compromise. .9 Nicolson's alternative is an approach of "virtue ethics," in which the focus is upon motivations and intentions, and the development of professional moral character, rather than compliance with duties or judging the

55. See Moore, supra note 31, at 542.

56. See Galanter \& Palay, supra note 20, at 200; Abel, Ten Years, supra note 26.

57. Donald Nicolson, Making Lawyers Moral? Ethical Codes and Moral Character, 25 LegaL STud. 601, 608 (2005) (U.K.); see also Charles Sampford \& Christine Parker, Legal Regulation, Ethical Standard-Setting, and Institutional Design, in Legal Ethics and Legal Practice: ContemPORARY Issues 11, 15 (Stephen Parker \& Charles Sampford eds., 1995) (arguing that externally imposed codes of conduct are only effective if combined with internalized ethical values).

58. Duty based approaches focus on preventing unethical behavior, rather than on promoting positive behavior, and are contrary to a deeper notion of positive morality. See Sampford \& Parker, supra note 57 , at $14-15$.

59. Nicolson, supra note 57, at 608. 
consequences of actions..$^{60}$ This comprises the gradual development of moral virtue and practical wisdom through actual engagement with moral issues. Thus, appropriate moral behavior, beliefs, and feelings become part of the individual's essential character. This might allow for a wider coverage of ethical issues than could be achieved in a code while respecting cultural diversity. In the words of Gonzales:

Virtue ethics favors cultural diversity precisely inasmuch as it rests on the acceptance of the natural foundation that forms the basis of the coherence of any culture and seeks, from this point of departure, the growth of the persons who share a lifestyle. ${ }^{61}$

It may well be that this virtue ethics approach is furthered by the presence of professional codes within different jurisdictions that have formed the basis of education and training for the lawyer and have provided a framework for the legal profession and "touchstone" for individuals to evaluate their actions. As such, they may be seen as "contextual codes," setting aspirational principles, detailed rules, and specific guidance on contextual factors that should be taken into account in resolving dilemmas. ${ }^{62}$ The development of business ethics fit for globalization has also identified internal guidance as increasingly important, shaped by external guidance, as economic actors enjoy more freedom, and so more responsibility, ${ }^{63}$ through the expansion of free markets and deregulation. The multi-jurisdictional workplace for many lawyers in international firms means that some kind of internal "moral compass" is at least as important as externally imposed duties, and the nature of their business makes this an essential part of the services which they offer.

\section{Setting the "Moral Compass"}

At one time, the starting point for ethical regulation of the legal profession, at least in England, was a homogenous social background whereby lawyers might have been expected to share the same beliefs and values. ${ }^{64}$ Social class may continue to have some effect on entry into the profession. Examination of the background of law graduates and their subsequent employment in the legal profession

60. Nicolson, supra note 57, at 611; Nicolson \& WebB, supra note 29, at 29-34; see also Alasdair Maclntyre, After Virtue: A Study in Moral Theory (2d ed. 1984).

61. González, supra note 53, at 33; accord Nicolson, supra note 57, at 612 .

62. Nicolson, supra note 57 , at 621.

63. Enderle, supra note 49, at 531 .

64. See Nicolson, supra note 57, at 613-14. 
suggests that students from state schools whose parents did not have a degree or qualification are more likely to work in smaller high street practices than in a City of London or large provincial firm. ${ }^{65}$ The distinction between the two hemispheres of practice was recognized in the United States in the early 1980s by Heinz and Laumann in their study of Chicago lawyers. ${ }^{66}$ By Chicago lawyers II ${ }^{67}$ not only had the corporate hemisphere cast that of the private client into shadow, but a twenty-year gap between 1975 and 1995 had seen striking changes in the ethnic, gender, and social composition of the large law firm, although "women and lawyers of color are disproportionately allocated to less prestigious practice settings." ${ }^{68}$

Increasingly, in both jurisdictions there is an erosion of a common background of large firm lawyers through at least two forces. The first is that the growing size and geographical scope of practices has seen an increasingly diverse range of lawyers (and clients) working together, albeit that their social "class" may be less heterogeneous than some other aspects of their relationship. The second is that firms servicing diverse clients have sought actively to recruit lawyers with experience in different cultures so that the firms are alive to, and comfortable with, a culturally diverse workplace. While this could possibly be seen as a disadvantage in seeking to set an ethical framework and develop consistent moral values for a national or local profession, it brings positive advantages for an organization that operates in a range of complex environments. Nicolson advocates the development of professional moral character primarily at the legal education stage, but sees development "[b]y emulating others, by trial and error, by instruction from authoritative others, and by experiencing the appropriate satisfaction or regret at the outcomes of one's actions." ${ }^{79}$

The diverse background of large firm lawyers could inhibit this in the sense

65. M. Shiner \& T. Newburn, Entry into the Legal Professions: The Law Student Cohort Study Year 3 (1995). See generally Phil Thomas \& Ashima Arora, Poverty, Privilege and Access to the Legal Profession: Barriers to Equality of Access for Law Students, 11 Welsh J. Educ. (Special Issue) 95 (2002) (discussing the influence of poverty and student financial support on access to training for law students in England and Wales and their subsequent employment).

66. John P. Heinz \& Edward D. Laumann, Chicago Lawyers: The Social Structure of the Bar 127-136 (Northwestern Univ. Press/Am. Bar Found. 1994) (1982).

67. John P. Heinz, Robert L. Nelson, Rebecca L. Sandefur \& Edward O. Laumann, Urban Lawyers: The New Social Structure of the Bar (2005).

68. Id. at 319.

69. Nicolson, supra note 57 , at 611 . 
of differences in approach to professional moral development in legal education. ${ }^{70}$ There is, however, evidence that some such firms are addressing the "double deontology" problem through the internalization of standards within the firm. By setting standards, the firms are becoming the primary site of ethical regulation in multi-national practice. ${ }^{71}$ The nature of large firms is such that they should be able to secure significant advantages in developing professional characteristics post-formal legal education, based on a character which is appropriate to globalized legal practice, through instilling enduring values that bridge cultural and geographical divisions. This may also be the source of competitive advantage when considering this issue from the "business" end of legal practice.

\section{The Role of the Firm}

There are a number of mechanisms by which firms can and do establish, maintain, and develop internal guiding norms and values, as well as disseminate legal knowledge and develop practice skills that can be used to develop a professional ethos. ${ }^{72}$ The first is the recruitment process. A hiring regime based on a strong behavioral model, that seeks to determine character traits by reviewing actions taken in real life situations, will look to isolate how people might react in a variety of stressful, awkward, or difficult situations, including those involving ethical determinations. This type of recruitment process can consider also the applicant's awareness of, and sensitivity to, different cultural contexts. A second mechanism is likely to be the firm's training program. Formal training may include reflection on, and discussion of, ethical issues, as well as guidance in the firm's approach, perhaps through role-play or other simulation. ${ }^{73}$ This type of experiential learning in a safe environ-

70. For example, German lawyers traditionally have little or no formal training in professional ethics, despite having a long and varied qualification period. Ross Cranston, Preface to Legal ETHics and Professional Responsibility, supra note 20, at v.

71. Nicolson \& WEBb, supra note 29, at 63; see Richard J. Maiman, Craig A. McEwan \& Lynn Mather, The Future of Legal Professionalism in Practice, 2 Legal Ethics 71, 74-75 (1999).

72. See generally Jeffrey Gandz \& Frederick C. Bird, Designing Ethical Organizations, Bus. Q., Autumn 1989, at 108 (discussing the positive steps that organizations must take to ensure that their employees act ethically); Kevin T. Jackson, Globalizing Corporate Ethics Programs: Perils and Prospects, 16 J. Bus. Eтнics 1227 (1997) (discussing both the difficulties and the possibilities involved in international corporate ethics programs).

73. See Alan Paterson, Legal Ethics: Its Nature and Place in the Curriculum, in Legal Ethics and Professional Responsibility, supra note 20, at 175, 184-85 (discussing how this is a particularly useful approach for ethics education, though it does have some potential pitfalls); Alan Paterson, Self-Regulation and the Future of the Profession, in Law's Future(s): British Legal. Developments 
ment, supported by tutors or mentors, might be particularly well suited to this task. In a sense, such training replaces an apprenticeship model in large firms where access to partners with relevant experience may be limited. ${ }^{74}$ To an extent, the elaborate checks made in relation to conflicts in large law firms might be seen as replacing the everyday dialogue that might take place in smaller firms where the entirety of the firm's business is known to all staff. Training to ensure that a less experienced lawyer is at least aware of the danger of an ethical trap similarly replaces a model of more direct supervision.

A second element of this kind of training is the softer "socialization" that generally accompanies formal training sessions, where informal peer discussions and observation can be at least as important as formal sessions. Third, there is the kind of "legitimate peripheral participation" that forms part of the development of professional knowledge, particularly for trainees and junior professionals. ${ }^{75}$ Observing how peers and more experienced professionals work in their day-today practice, together with the undertaking of increasingly less peripheral tasks, is a highly effective method of inculcating the kind of tacit knowledge and skills that are difficult to develop through other means. ${ }^{76}$ Socialization can be encouraged outside of formal training sessions through identifying and supporting informal activities so as to develop "communities of practice" 77 and to enhance development of professional moral character. In resolving tensions that do arise, law firms may be in a position to "eclectically integrate the virtues of various cultures and, through the process of mutual consultation and conflict resolution, distribute an ethically sound decision-making procedure." ${ }^{78}$ Finally, there is codified

IN The 21st Century 29, 49 (David Hayton ed., 2000) (discussing the importance of reflexivity in responsive regulation).

74. Elizabeth Nosworthy, Ethics and Large Law Firms, in Legal Ethics and Legal Practice: CONTEMPORARy Issues, supra note 57, at 57,65-66.

75. Jean Lave \& Etienne Wenger, Situated Learning: Legitimate Peripheral ParticipaTION 29 (1991).

76. Id.

77. See, e.g., Etienne Wenger, Communities of Practice: Learning, Meaning, and Identity 6-7 (1998); John Seely Brown \& Paul Duguid, Organizational Learning and Communities-of-Practice: Toward a Unified View of Working, Learning, and Innovation, 2 Org. ScI. 40, 47-48 (1991). The role of a 'community of practice' is similar to the role played by 'quality circles' or 'ethical circles' through which professional moral character can contribute to shared morality within a firm. Sampford \& Parker, supra note 57, at 17. In a sense, the former processes of socialization that inculcated ethical norms at the level of the profession may be replaced by these 'varied and contingent' processes at the firm level. See Francis, supra note 9, at 174.

78. Ashay B. Desai \& Terri Rittenburg, Global Ethics: An Integrative Framework for MNEs, $16 \mathrm{~J}$. Bus. ETHICs 791, 797 (1997). 
guidance and support through knowledge management systems that generally include precedents, file opening procedures, and contextual or background documents, etc. This is probably the least effective method, though it may be a useful means of supporting and reinforcing development through other means. All of these methods can be enhanced by the movement of lawyers around different locations and between practice areas.

\section{Advantages for the Firms}

The development of a professional ethos as a means of creating ethical governance has advantages for the individual lawyer. It supports notions of autonomy that are highly valued by professionals, and lawyers in particular. While such development as part of a firm-specific process might appear to restrict mobility, in fact the multi- and inter-cultural experience should more than compensate the individual. The increasing size and decreasing number of truly global law firms are also limiting the opportunities to move from one firm to another doing similar work. Provided that an individual cares about ethical matters, it should also provide an effective method of maintaining high ethical standards within complex professional contexts.

Given the time, resources, and energy invested in these mechanisms for professional development, recognition of the benefits to the firm itself may be vital. Most firms are genuinely committed to ethical principles, either through belief in the long term benefit from acting ethically, or because of a shared commitment to virtue as a product of a professional ethos into which they have been inculcated. The danger with the former commitment is that it may be abandoned where it seems that less than ethical behavior might deliver more immediate advantages. Shorter term benefits as measured by billings or career advancement might appear to have greater attraction. ${ }^{79}$ But gambling short-term reward against longterm probity is a high-risk game as best illustrated by the catastrophic effect of the Enron case on Arthur Andersen. The risk to reputation and the need to develop and sustain the firm's brand suggest the wisdom of a shared ethical approach across all offices as part of the "DNA" of the firm. ${ }^{80}$

79. Sampford \& Parker, supra note 57, at 14.

80. For an illustration, see Jon Ashworth, Clifford Chance Denies Young Lawyers' Charges, Times (London), Oct. 29, 2002, at 31, which gives details of a 13-page leaked memo from associates to partners in the New York office, in part explaining why the firm scored so poorly in the American Lawyer Associates' Survey for 2002. One part of the memo reads as follows: "Associates stated that the [billing] requirement is profoundly unrealistic, particularly in slow areas of the firm. More- 
As indicated above, the corporate clients of the large law firms are increasingly being called to account for their global actions by government and civil society within developing models of Corporate Social Responsibility (CSR). In this context, multi-national corporations are likely to seek advisors who pursue their own CSR program and who can assist in enhancing rather than undermining the client's CSR profile. The larger law firms grow, the more complex their client relationships become, so that vigilant lawyers pursuing a consistent approach to ethical standards become an important safeguard in maintaining and developing business relationships. At the macro level, notwithstanding the fragmentation that globalization brings to professional ethics, the failure to operate at a high ethical level threatens the justification for having a profession at all. It has been said that " $[t]$ he most consistent and successful firms ... will be those who remember that the practice of law is both a business and a profession," "st and that the future of the legal profession depends upon finding ways of maintaining high ethical standards despite problems of size and geographical spread. ${ }^{82}$

Mayson believes that while global law firms should resist cultural imperialism and standardization, global management through the setting of a context or framework is vital: "avoiding standardisation does not mean ... [the abandonment of] global standards of client commitment and service quality. ${ }^{, 83}$ Clearly, legal ethics provide a vital element of such a framework, though there will also be more widely shared values and aspects of internal culture that a firm will want to establish and reinforce. This normative environment is generally considered to be the most important asset for a professional service firm, on which all strategic options are dependent. ${ }^{84}$ The establishment of an organizational ethical framework should also help the organization to measure up to individual lawyers' expectations and to admonish

over, associates found the stress on billable hours dehumanizing and verging on an abdication of our professional responsibilities insofar as the requirement ignores pro bono work and encourages 'padding' of hours, inefficient work, repetition of tasks, and other problems." Memorandum from the Clifford Chance New York Associates to the Clifford Chance New York Partners (Oct. 15, 2002), available at http://www.lawcost.com/clifchancememo.htm.

81. Stephen Mayson, Making Sense of Law Firms: Strategy, Structure and Ownership 17 (1997).

82. See Mark, supra note 1, at 1213.

83. Stephen Mayson, Globalisation of Legal Practice 7 (Nottingham Law Sch., The Ctr. for Law Firm Mgmt., Working Paper No. 01, 1998), available at http://www.mayson.co.uk/working.htm (upon request).

84. Stephen Mayson, Levels of Strategy 3-4 (Nottingham Law Sch., The Ctr. for Law Firm Mgmt., Working Paper No. 03, 2001), available at http://www.mayson.co.uk/working.htm (upon request). 
in the event of a failure to maintain espoused values and principles. ${ }^{85}$ Putting ethical development at the heart of cultural socialization within a firm should help to provide the dual benefits of strengthening the ethos of the firm, thereby generating competitive advantages, and strengthening the wider legal profession by developing lawyers with a strong and clear moral compass, which allows them to negotiate the pathways of global legal practice.

While organizational culture is of great importance for the development of ethics in legal practice at all levels of the profession, ${ }^{86}$ there are some potential disadvantages to having the development of professional ethics internalized within firms, and as part of the development of wider culture. Lawyers generally value their autonomy and individualism and so may be thought to be naturally resistant to such an approach. The benefit of a virtue ethics model is that the general framework is designed to be flexible, so that cultural and other differences are embraced while general standards, such as service quality, are provided. In addition, successful firms are unlikely to want to stifle the individuality and creativity through which competitive advantage will often arise. Indeed more of a concern is the issue of "groupthink," which an internalized ethical standards process might produce. The dangers of producing and reinforcing inappropriate values and behavior, however, might be offset by the diversity of the individuals involved, while the process of continuing development should mean that a firm's moral compass is constantly challenged by diverse views, with reduced danger of stagnation through self-reference. "[A]t its core, [professional] ethics should be seen as a form of critical morality in which individuals can debate, discuss, and criticize majority views," ${ }^{87}$ so that this approach could positively benefit firms and society alike. This must be subject also to external influence through the context of regulatory frameworks and through the market.

In our own jurisdiction, the mix of market, external, and self-regulation is set for major change. ${ }^{88}$ Garth and Silver have argued that the competitive elements of globalization have altered organizational forms consisting of hybrid entities best constituted with a mix of human capital to deliver the services demanded in the

85. See Sampford \& Parker, supra note 57, at 17.

86. See generally Andrew Boon \& Jennifer Levin, The Ethics and Conduct of Lawyers in ENGLAND AND WALES 68-96 (1999) (examining the ability of the legal profession to sustain a community with common norms as differences within the profession increase).

87. Sampford \& Parker, supra note 57, at 16.

88. See generally R. Baldwin, M. Cave \& K. Malleson, Regulating Legal Services: Time for the Big Bang?, 67 MoD. L. REv. 787 (2004) (discussing the potential reform of the regulatory framework governing legal services). 
global marketplace.$^{89}$ In the United Kingdom, the notion of multidisciplinary services has given way to the wider concept of Legal Disciplinary Practices-the provision of legal services through law practices not all of whose managers will necessarily be solicitors, or for that matter even qualified lawyers, by allowing that lawyers and non-lawyers can form Legal Partnerships. ${ }^{90}$ Overseeing these entities will be a single oversight body, independent from both the government and existing regulators such as the Law Society and the Bar Council. Alongside this will be an Independent Office for Legal Complaints, a body with statutory power to handle complaints concerning providers of legal services and to award redress to consumers.

In this much changed world, how influential will professional bodies remain? Will they effectively regulate alongside the external regulators, or will they become lobbyists seeking to protect the profession from such bodies? If the professional bodies slip into gradual decline, will the law firms internalize even further issues of legal ethics to ensure protection from regulatory sanction? And in these Legal Practices, how might we decide which work is "legal," and which is not? Or when a partner is acting as a lawyer, and when not? In such circumstances, the growth of internal, firm-based conduct rules seems inevitable and a model based on virtue ethics, a more flexible tool for delivery.

\section{Conclusion}

In this paper we argued that the forces of globalization have both spatial and temporal impacts, necessitating the accommodation of the delivery of legal services across jurisdictions at the same time as traditional regulatory structures are crumbling away within those jurisdictions under market pressures that reflect the globalization enterprise. This accommodation is made more complex by the cultural location and application of ethical rules, such that overarching transnational conduct rules have gained little purchase. Increasingly, the international law firm will represent the seat of legal ethics. While this is worrying in some respects, a system based on virtue ethics would seem to have the capacity and the flexibility to step up to this task, and many firms already have the mechanisms in place to

89. Bryant G. Garth \& Carole Silver, The MDP Challenge in the Context of Globalization, 52 CasE W. Res. L. Rev. 903, 939 (2002).

90. Explanatory Notes and Assessment, supra note 39, at 37-39. For a critique of the alternative business structures, see Harry McVea, Legal Disciplinary Practices-Who Needs Them?, 31 J.L. \& Soc'y 563 (2004) (Eng.). 
promulgate such systems. What will remain to be tested is whether the likely dilution of the power of professional conduct rules, traditionally overseen by an independent domestic bar, will be adequately replaced by the commercial pressures of international firms to maintain the highest standards of ethical conduct. Indeed, much may depend upon the capacities of these firms to identify and fulfill ethical obligations in global settings. Ultimately, competitive advantages may well accrue to those firms that are best able to address these problems and develop a framework to deliver consistent and high standards of conduct but which remain sufficiently flexible to meet both the client's and society's needs in a variety of cultural environments. 